\title{
Rootstock and Scion Compatibility Studies in Tomato under Protected Conditions
}

\author{
Vibhuti Sharma ${ }^{*}$, Pardeep Kumar ${ }^{1}$, Parveen Sharma ${ }^{1}$, N.D. Negi ${ }^{2}$, Amar Singh ${ }^{3}$, \\ Pawan K. Sharma ${ }^{4}$, Navjot Singh Dhillon ${ }^{1}$ and Binny Vats ${ }^{1}$ \\ ${ }^{1}$ Department of Vegetable Science and Floriculture, ${ }^{2}$ Department of Horticulture, \\ ${ }^{3}$ Department of Plant Pathology, ${ }^{4}$ Department of Entomology, CSKHPKV, Palampur \\ (India)-176062
}

*Corresponding author

\section{Keywords}

Grafting, Grafting

success rate,

Solanaceous, number of fruits,

Average fruit weight, Marketable fruit yield per plant, Marketable yield per square metre

Article Info

Accepted:

12 April 2019

Available Online:

10 May 2019

\section{A B S T R A C T}

The present research was conducted for two cropping seasons (2016-17 and 2017-18) to study the compatibility reaction and to estimate grafting success rate (\%) among different solanaceous rootstocks grafted on scion 'GS-600' which was horticulturally superior. The experimental material consisted of thirteen different rootstocks in a Randomized block design (RDB) having three replications. Different rootstocks viz., Hawaii-7998, Hawaii7996, LS-89, Green Gourd, Back Attack, Palam Pink, Palam Pride, VI-34845, VI-45376, VI-47335, Arka Nidhi, Arka Keshav and Solanum torvum. Grafting success rate (\%) was found out by counting number of plants which survived till the end of trial to the number of successful grafts and multiplying with 100. Results revealed that different rootstocks had higher grafting success rate ranging from (92-97.33\%). Maximum grafting success rate was found in plants grafted on rootstock Hawaii-7998 during both the years of study as well as in pooled analysis of data. Maximum number of fruits, average fruit weight, marketable yield per plant and marketable yield per square metre was recorded in plants grafted on rootstock Green Gourd. Therefore, it can be concluded that tomato scion 'GS600 ' was found highly compatible for different solanaceous rootstocks and further, these rootstocks can be further used to in obtaining higher survived plants under protected conditions along with higher yields.

\section{Introduction}

Grafting using appropriate rootstock/scion combinations helps in combating various biotic and abiotic stresses (Negi et al., 2016). Grafting reaction within the same species is considered compatible (Kawaguchi et al., 2008). So these combinations are widely used in obtaining higher success in grafting. Generally, rootstocks and more vigorous and have wider rootsystem (Martinez-Ballesta et al., 2010). By using rootstocks that have vigorous root system, helps in improved nutrient, water and mineral uptake which help in obtaining higher yields per square metre (Ruiz et al., 1997). Although grafted plants 
are higher yielder than non-grafted ones, but to obtain higher yield in terms of quantity and quality proper rootstock/scion combinations have to carefully selected (Martinez-Ballesta et al., 2010; Leonardi and Giuffrida, 2006). For ensuring successful graft union formation, following conditions should be fulfilled (i) callus proliferation, both from the rootstock and the scion. (ii) Callus bridge formation (iii) differentiation of new vascular tissue from callus cells and (iv) production of secondary xylem and phloem (Andrews and Marquez, 1993; Hartman et al., 1977).

The vascular connection between rootstock and graft may interfere with water uptake and salt translocation (Santa-Cruz et al., 2002; He et al., 2009). Affecting several physiological characteristics if the rootstock/scion combinations are not selected (Abdelmageed and Gruda 2009; Martinez-Ballesta et al., 2010). In this way, there are losses in the physiological processes of the plant, which reduces vegetative development and fruit production. In contrast, a good connection between rootstock and grafting ensures constant flow of water from rootstock to graft, promoting greater plant growth, nutrient uptake and photosynthetic yield (MartinezBallesta et al., 2010).

\section{Materials and Methods}

Experiment was carried out in a modified naturally ventilated polyhouse at Vegetable Research Farm, Department of Vegetable Science and Floriculture, CSKHPKV, Palampur which is situated at an elevation of $1,290.8 \mathrm{~m}$ above mean sea level with 320 6' $\mathrm{N}$ latitude and 760 3' E longitudes.

The polyhouse used for research trial had all the essential features of an ideal polyhouse such as double door, side \& top ventilation, drip irrigation and shading with 50 per cent green agro UV stabilized shade net.

\section{Nursery sowing of rootstocks and scion}

The nursery of rootstocks and scion were raised in plastic plug trays having uniform size and cells of equal size using soil-less media (cocopeat: perlite: vermiculite) in the ratio of $3: 1: 1$, respectively in the growth chamber of Department of Vegetable Science and Floriculture CSKHPKV, Palampur.

One seed was sown per cell by making small depression $(0.5 \mathrm{~cm})$ with finger so as to ensure that seed is kept in the centre of cell. Seeds of tomato, brinjal, chilli rootstocks were sown in plug trays having 98 small cells. Water was sprayed initially through rose can and trays were covered with net so that seeds do not come outside. Trays were regularly monitored and checked and on emergence of germination the net was removed. All the necessary precautions were observed for raising healthy seedlings.

Rootstocks were sown one week earlier than scion so that the diameter of both the stems matches with each other for ensuring successful grafting. For the first season trial sowing of rootstocks was done on $19^{\text {th }}$ July 2017 and sowing of scion on 26th July 2017.

For the second season trial rootstocks were sown on $7^{\text {th }}$ February 2018 and sowing of scion was done on $15^{\text {th }}$ February 2018. After 4-7 days of germination seedlings were sprayed with Polyfeed (19:19:19) @ 2g/lt for developing stronger stems and to ensure sturdiness. Fertigation was done twice a week to get healthy nursery. The seedlings were sprayed with water twice or thrice depending on climatic conditions. The seedlings were grown in plug trays so as to ensure that seedlings do not suffer transplanting shock. Optimum temperature was provided for germination. Tomato seedlings emerged in 15-20 days at $\left(21-24^{0} \mathrm{C}\right)$ and Brinjal in 25-30 days at $\left(26-28^{0} \mathrm{C}\right)$. 


\section{Grafting}

The scion variety GS-600 was grafted on various rootstocks using cleft grafting on attaining graftable height of $15-20 \mathrm{~cm}$ with stem thickness of 5-10 $\mathrm{mm}$ to ensure higher grafting success rate and compatibility. Scion seedlings were grafted on various rootstocks on $24^{\text {th }}, 26^{\text {th }}$ and $27^{\text {th }}$ August 2017, while transplanting was done on $12^{\text {th }}$ September 2017. Whereas, during 2018 seedlings were grafted on $12^{\text {th }}, 14^{\text {th }}$ and $15^{\text {th }}$ April 2018 and transplanting was done on $24^{\text {th }}$ May, 2018. Graft union was secured with a grafting clip to ensure good vascular connection and to ensure complete healing of grafted portions.

\section{Aftercare and handling}

Immediately after grafting the plants were sprayed with water and were kept inside grafting chamber (healing chamber) for 3-4 days. Water was sprayed on grafted plants during day once or twice depending on weather conditions so as to avoid wilting and ensure complete healing. For successful healing of grafted seedlings reduced light intensity, moderate temperature $\left(25-30^{\circ} \mathrm{C}\right)$ and high relative humidity $(85-90 \%)$ are essential to establish good vascular connection and continue to grow as single plant. On an average tomato took 2-3 days and brinjal 3-5 days for complete and strong vascular union when such conditions were maintained and care taken fully for a specific period of time. After completion of healing processes the plastic clips were removed from graft union so as to avoid cessation and stunted growth of plants.

\section{Acclimatization}

For acclimatization grafted seedlings were taken outside the healing chamber and kept under sunlight so as to provide hardening prior to transplanting and to reduce transplanting shock. On an average grafted seedlings took three to four days for complete acclimatization and later they were transplanted in well prepared beds inside naturally ventilated polyhouse.

Observations were made on grafting success rate $(\%)$ in the following manner:

Total number of plants survived till the end of trial

Number of successful grafts

\section{Results and Discussion}

The analysis of variance indicated that all the grafted plants exhibited an appreciable grafting success rate, which ranged between 92.00-97.33\%. Data shown in Table 1 clearly depicts that in the year 2016-17 plants grafted on rootstock Hawaii-7998 showed higher success rate (97.33\%). Rootstocks viz., Palam pride $(96.67 \%)$, LS-89 (96.59\%), VI-45376 (96.33\%), Green Gourd (96.14\%), Hawaii7996 (96.00\%), Arka Keshav (95.00\%) and Solanum torvum (95.67\%). Were found statistically at par. Similarly in the year 201718 plants grafted on rootstock Hawaii-7998 also showed higher success rate $(96.67 \%)$ and was at par with rootstocks Palam Pride (95.11\%), Palam Pink (96.55\%), Hawaii-7996 (95.33\%), LS-89 (94.67\%), VI-34845 (95.00\%), Arka Nidhi (95.67\%), Arka Keshav (96.59\%), VI-47335 (94.33\%) and VI-45376 $(95.33 \%)$. The pooled analysis of data also showed high success rate $(97.00 \%)$ in Hawaii7998 rootstock. In rootstocks PI-201232, AVPP0205 and Local Pumpkin no grafting success rate(\%) was recorded as none of them survived till the end of trial due to poor rootstock-scion vascular union which ultimately lead to poor compatibility.

Higher grafting success rate in grafted plants may be attributed to compatibility between rootstock and scion, good callus formation, vascular bundle differentiation and 
connectivity at the graft interface which ensured successful graft union through proper healing and also due to lack of transplanting shock. Similar results were reported in the findings of (Ogata et al., 2005).

\section{Number of marketable fruits per plant}

Number of fruits is an important factor which contributes remarkably for total yield on a plant or per hectare basis. To obtain higher yield number of fruits per plant should be more with marketable quality and fruit weight.

Rootstocks significantly affected the number of fruits per plant as evident from the (Table 2). Plants grafted on rootstock Green Gourd produced maximum number of marketable fruits per plant (24.33) during 2016-17 which was statistically at par with Palam Pride (22.67). Whereas, in 2017-18 highest number of marketable fruits per plant were also observed in plants grafted on rootstock Green Gourd (23.00) which were at par with Arka Keshav (22.67), Back Attack (22.33), VI45376 (22.33), Solanum torvum (22.67), LS89 (22.67), Palam Pride (21.33) and VI-47335 (21.00).

Pooled analysis of data also showed maximum number of fruits per plant in plants grafted on rootstock Green Gourd (23.67) followed by Solanum torvum (21.67), Arka Keshav (21.17), and VI-47335 (21.17). Nongrafted plants recorded $32.40 \%$ less number of marketable fruits than grafted. The increased number of marketable fruits in grafted plants as compared to non- grafted was due to use of vigorous rootstocks which led to improvement of cytokinin content in scion which ultimately improved fruit load on the plants. Similar findings were also reported by Fernandez et al., (2013), Kumar et al., (2017), Rahmatian et al., (2014), Tamilselvi and Pugalendhi (2017) and Velkov and Pevicharova (2016).

\section{Average fruit weight (g)}

Rootstocks had significant effects on average fruit weight of tomato during both the years (Table 2). Plants grafted on rootstock Green Gourd recorded highest average fruit weight (90.83 g) followed by rootstock Palam Pride (88.66 g) during 2016-17. Whereas, plants grafted on rootstock Green Gourd also recorded highest average fruit weight (92.17 g) during 2017-18 followed by Palam Pride (85.85 g), Arka Keshav (84.25 g), LS-89 (81.15 g), Palam Pink (80.70 g) and Hawaii7998 (80.67 g). Similarly, pooled analysis of data also showed maximum average fruit weight in plants grafted on rootstock Green Gourd $(91.50 \mathrm{~g})$ which was followed by Palam Pride (87.25 g), Arka Keshav (85.34 g), Palam Pink (81.88 g) and VI-45376 (80.33 g). Non-grafted plants recorded $24.06 \%$ less fruit weight in comparison to grafted ones. Higher average fruit weight in grafted plants might be due to interactions between rootstocks and scion which influenced more efficient uptake of minerals, water and nutrients throughout the plant system. Results are supported by the conclusions drawn from the findings of Fernandez et al., (2013), Moncada et al., (2013), Rahmatian et al., (2014) and Riga 2015.

\section{Marketable fruit yield per plant (kg)}

It is apparent from the data presented in the (Table 2) that different rootstocks affected the fruit yield per plant significantly. Plants grafted on rootstock Green Gourd produced maximum fruit yield per plant $(2.21 \mathrm{~kg})$ followed by Palam Pride $(2.01 \mathrm{~kg})$, VI-45376 $(1.82 \mathrm{~g})$ and Palam Pink (1.80 g). In the year, 2017-18 maximum fruit yield was also recorded in plants grafted on rootstock Green Gourd $(2.12 \mathrm{~kg})$ which was followed by Arka Keshav (1.91 kg), LS-89 (1.84 kg) and Palam Pride $(1.83 \mathrm{~kg})$. 
Table.1 Effect of rootstocks on grafting success rate (\%) in tomato under protected conditions

\begin{tabular}{|c|c|c|c|}
\hline Rootstocks & $\mathbf{2 0 1 6 - 1 7}$ & $\mathbf{2 0 1 7 - 1 8}$ & Pooled \\
\hline Back Attack (Tomato) & 94.33 & 93.85 & 94.09 \\
\hline Palam Pride (Tomato) & 96.67 & 95.11 & 95.89 \\
\hline Palam Pink (Tomato) & 93.67 & 96.55 & 97.11 \\
\hline Hawaii-7998 (Tomato) & 97.33 & 96.67 & 95.15 \\
\hline Green Gourd (Tomato) & 96.14 & 94.15 & 95.67 \\
\hline Hawaii-7996 (Tomato) & 96.00 & 95.33 & 95.63 \\
\hline LS-89 (Tomato) & 96.59 & 94.67 & 93.50 \\
\hline VI-34845 (Brinjal) & 92.00 & 95.00 & 94.20 \\
\hline Arka Nidhi (Brinjal) & 92.74 & 95.67 & 95.80 \\
\hline Arka Keshav (Brinjal) & 95.00 & 96.59 & 94.17 \\
\hline Solanum torvum (Brinjal) & 95.67 & 92.67 & 93.83 \\
\hline VI-47335 (Brinjal) & 93.33 & 94.33 & 95.83 \\
\hline (EG-195) & & & 0.00 \\
\hline VI-45376 (Brinjal) (EG-203) & 96.33 & 95.33 & 0.00 \\
\hline PI-201232 (Chilli) & 0.00 & 0.00 & 0.00 \\
\hline AVPP0205 (Chilli) & 0.00 & 0.00 & 1.97 \\
\hline Local Pumpkin & 0.00 & 0.00 & 1.58 \\
\hline CD (0.05) & 2.80 & 2.51 & \\
\hline CV (\%) & 2.24 & 2.00 & \\
\hline
\end{tabular}


Table.2 Effect of rootstocks on yield and other contributing traits in tomato under protected conditions

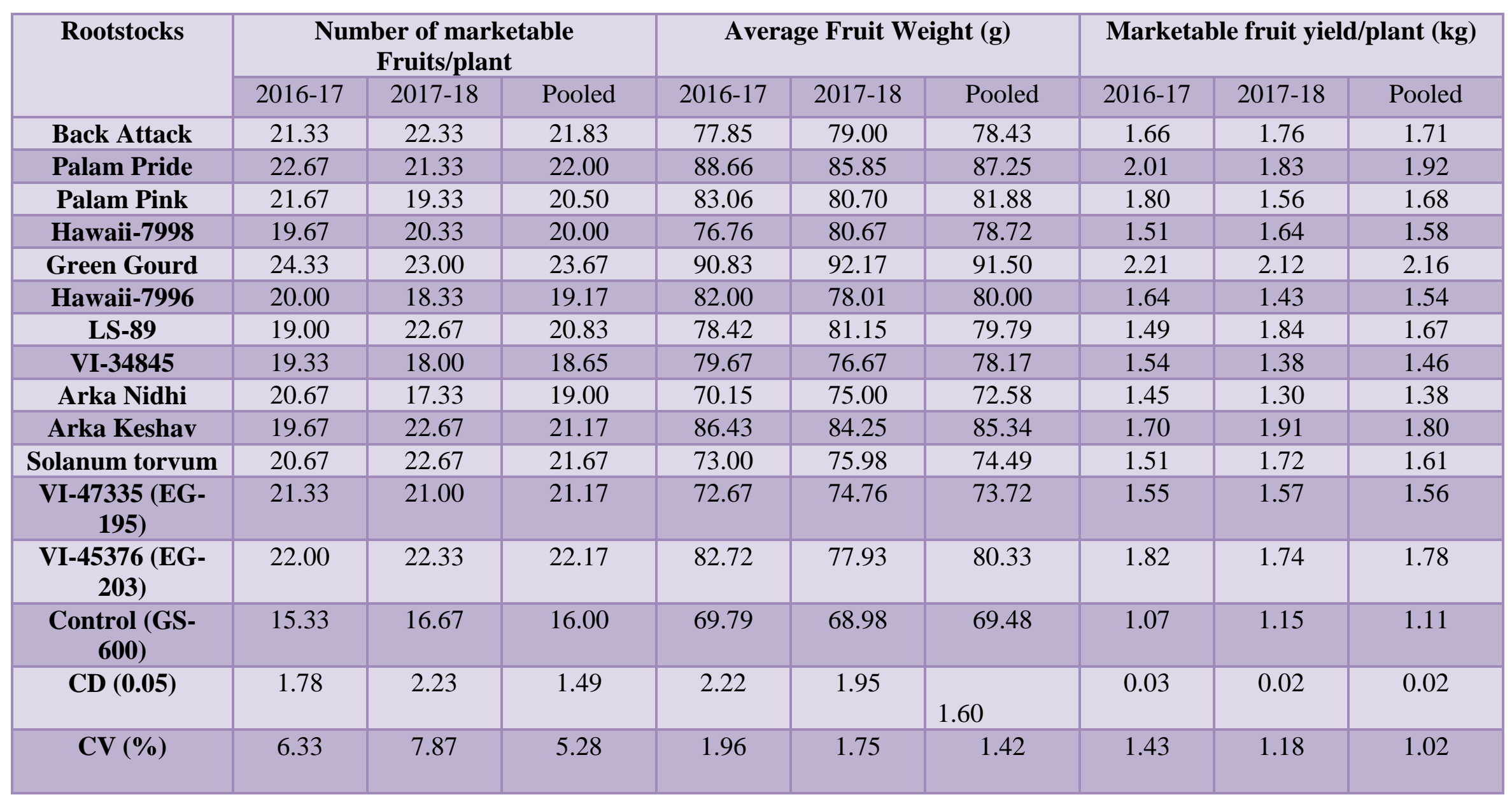


Table.3 Effect of rootstocks on marketable yield /square metre in tomato under protected conditions

\begin{tabular}{|c|c|c|c|}
\hline \multirow[t]{2}{*}{ Rootstocks } & \multicolumn{3}{|c|}{ Marketable fruit yield/sq.m $\left(\mathrm{kg} / \mathrm{m}^{2}\right)$} \\
\hline & 2016-17 & $2017-18$ & Pooled \\
\hline Back Attack & 19.92 & 21.12 & 20.52 \\
\hline Palam Pride & 24.12 & 21.96 & 23.04 \\
\hline Palam Pink & 21.60 & 18.72 & 20.16 \\
\hline Hawaii-7998 & 18.12 & 19.68 & 18.90 \\
\hline Green Gourd & 26.52 & 25.44 & 25.92 \\
\hline Hawaii-7996 & 19.68 & 17.16 & 18.42 \\
\hline LS-89 & 17.88 & 22.08 & 20.04 \\
\hline VI-34845 & 18.48 & 16.56 & 17.52 \\
\hline Arka Nidhi & 17.40 & 15.60 & 16.50 \\
\hline Arka Keshav & 20.40 & 22.92 & 21.66 \\
\hline Solanum torvum & 18.12 & 20.64 & 19.38 \\
\hline VI-47335 (EG-195) & 18.60 & 18.84 & 18.72 \\
\hline VI-45376 (EG-203) & 21.84 & 20.88 & 21.36 \\
\hline Control (GS-600) & 12.84 & 13.80 & 13.32 \\
\hline CD $(0.05)$ & 0.96 & 1.18 & 0.74 \\
\hline CV (\%) & 5.04 & 6.25 & 3.90 \\
\hline
\end{tabular}


Pooled analysis of data showed that plants grafted on rootstock Green Gourd resulted in maximum yield per plant $(2.16 \mathrm{~kg})$ followed by Palam Pride (1.92kg), Arka Keshav $(1.80 \mathrm{~kg})$ and VI-45376 (1.78 kg). Thus, grafted plants produced $48.61 \%$ more yield than non-grafted.

The differences in yield response observed may be due to method of grafting, different growth characteristics of cultivars and different response to grafting, growth period and compatibility of rootstock and scions. Higher yield in grafted plants is attributed to resistance provided by the rootstocks against soil borne diseases (Bacterial wilt \& Nematodes), better absorption and translocation of phosphorus, nitrogen, magnesium and calcium which leads to improved nutrient uptake as rootstocks have well developed and strong root systems which release more cytokinins into the xylem sap resulting in increased yield and also due to increase of the rate of photosynthesis. Similar findings were reported by Aloni et al., (2010), Bogoescu and Doltu (2015), Blestos et al., (2003), Lee (1994), Marsic and Osvald (2004) and Pulgar et al., (2000).

\section{Marketable fruit yield per square metre (kg)}

From the Data presented in the Table 3 it is inferred that rootstocks exerted significant influence on yield per square metre. During 2016-17, Maximum yield per square metre was obtained in plants grafted on rootstock Green Gourd (26.52 kg) followed by Palam Pride (24.12), VI-45376 (21.84 kg), Palam Pink (21.60 kg) and Arka Keshav (20.40 kg). In the year, 2017-18 maximum yield per square metre was also reported in plants grafted on rootstock Green Gourd $(25.44 \mathrm{~kg})$ followed by Arka Keshav (22.92 kg), LS-89 (22.08 kg), VI-45376 (20.88 kg) and Solanum torvum $(20.64 \mathrm{~kg})$.
Pooled analysis of data also showed maximum yield per square metre in the rootstock Green Gourd (25.92 kg) followed by Palam Pride $(23.04 \mathrm{~kg})$, Arka Keshav (21.66 kg), VI-45376 (21.36 kg), Back Attack (20.52 kg) and LS-89 (20.04 kg). Grafted plants produced $48.61 \%$ more yield per square metre than non-grafted. The higher marketable yield obtained by grafting was due to an improvement in water and nutrient uptake by the vigorous rootstocks more efficiently, prolonged harvest duration, earliness in flowering and fruiting, increased fruit weight, number of fruits per plant, rootstock scion combinations, or due to low sunlight and low carbon-dioxide content in greenhouses during winter months.. These results are in conformity with the findings of Alvarado et al., (2017), Al-Harbi et al., (2016), Kyriacou et al., (2017), Rahmatian et al., (2014) and Turkmen et al., (2010).

In conclusion, results revealed that different rootstocks had higher grafting success rate ranging from (92-97.33\%) (Table 1). Maximum grafting success rate was found in plants grafted on rootstock Hawaii-7998 during both the years of study as well as in pooled analysis of data. Therefore, it can be concluded that tomato scion 'GS-600' was found highly compatible for different solanaceous rootstocks and further, these rootstocks can be further used to in obtaining higher survived plants under protected conditions. Maximum number of fruits, average fruit weight, marketable yield per plant and marketable yield per square metre was recorded in plants grafted on rootstock Green Gourd. A good connection between rootstock and grafting ensured constant flow of water from rootstock to graft, promoted greater plant growth, nutrient uptake and photosynthetic yield. Similar results were reported in the findings of (Martinez-Ballesta et al., 2010). 


\section{Acknowledgement}

Iam highly thankful to Department of Vegetable Science and Floriculture, CSKHPKV, Palampur for successful completion of research work.

Conflict of Interest: The Authors declare that there is no conflict of interest.

\section{References}

Aloni, B, Cohen, R, Karni, L, Aktas, H and Edelstein and C.M. 2010. Hormonal signaling in rootstock-scion interactions. Scientia Hortic. 127, 119126.

Alvarado, M.J.V, Ortiz, R.L., Zaval, J.J.G, Brindis, R.C, Izquierdo, S.C, Torres, T.C. and Mariano M.K.M. 2017. Mexican native tomatoes as rootstock to increase yield. Chilean J. Agric. Res. 77 187-193.

Al-Harbi, A, Hejazi, A and Al-Omran. 2016. Responses of grafted tomato (Solanum lycopersicum L.) to abiotic stresses in Saudi Arabia. Saudi J. Bio Sci. 23 2-7.

Bletsos, F, Thanassoulopoulos, C and Roupakias. D. 2003. Effect of grafting on growth, yield, and verticillium wilt of eggplant. Hortsci 38 183-186.

Bogoescu and Doltu. Effect of grafting eggplant (Solanum melongena L.) on its selected useful characters. 2015. Bulletin of University of Agricultural Sciences and Veterinary Medicine ClujNapoca Horticulture. 72 319-326.

Fernandez, C.L., Hernandez, H.G., Colın, C.N., Lopez, J.A., Reyes, S.V. and Castellanos, J.Z. 2013. Morphological response and fruit yield of sweet pepper (Capsicum annuum L.) grafted onto different commercial rootstocks. Bio Agric and Hortic. 29 1-11.

Abdelmageed A.H.A and Gruda N. 2009. Influence of grafting on growth, development and some physiological parameters of tomatoes under controlled heat stress conditions. E. J. Hortic. Sci. 74 16-20.

Andrews P. K. and Marquez C. S. Graft incompatibility. 1993. Hort Rev. 15 183-232.

Flores, F.B., Bel P.S., Estan M.T., Rodriguez M.M.M, Moyano, E, Morales, B, Campos J.F., Abellan, J.O.G, Egea, M.L., Garcia, N.F., Romojaro, F and Bolarin M.C. 2010. The effectiveness of grafting to improve tomato fruit quality. Scientia Horti.125 211-217.

Hartmann, H.T., Kester, D. E., Davies, F.T. and Geneve, R. L. 1997. Plant Propagation: Principles and Practices. Prentice Hall,Upper Saddle River,NJ,USA.770 pp.

He, Y, Zhu, Z, Yanga, J, Xiaole,i N, Zhua B. 2009. Grafting increases the salt tolerance of tomato by improvement of photosynthesis and enhancement of antioxidant enzymes activity. Environ. Exper. Bot. 66 270-278.

Kawaguchi, M, Taji, A, Backhouse, D and Oda M. 2008. Anatomy and physiology of graft incompatibility in solanaceous plants. J. Hortic. Sci. Biotechnol. 83 581-588.

Kumar, P, Sharma, P and Vats.B. 2017. Effect of grafting tomato on different rootstocks under protected environment in mid hills of NW Himalayan region. Agric. Sci. Digest. 37 81-82.

Kyriacou, M.C., Rouphael, Y, Colla, G, Zrenner, R and Schwarz, D. 2017. Vegetable Grafting: The Implications of a Growing Agronomic Imperative for Vegetable Fruit Quality and Nutritive Value. Front Plant Sci. 741 1-23.

Lee, J.M. Cultivation of grafted vegetables I. 1994. Current status, grafting methods and benefits. Hort Sci. 29 235-239.

Leonardi C and Giuffrida F. 2006. Variation of plant growth in grafted tomatoes and 
eggplants. E. J. Hortic. Sci. 71 97-101. Martinez-Ballesta, M.C, Alcaraz-Lopez, C, Muries, B, Mota-Cadenas, $\mathrm{C}$ and Carvajal. M. 2010. Physiological aspects of rootstock-scion interactions. Scientia Horti. 127 112-118.

Martinez-Rodriguez, M.M., Santa-Cruz, A, Estan, M.T., Caro, M, and Bolarin, M.C. 2002. Influence of rootstock in the tomato response to salinity. Acta Horticulturae. 573 455-460.

Marsiac, N.K. and Osvald. J. 2004. The influence of grafting on yield of two tomato cultivars (Lycoperscium esculentum Mill.) grown in a plastic house. Acta agric. slovenica 83243 249.

Negi V, Kumar P, Sharma P, Raj D, Singh A and Vats B. 2016. Graft compatibility studies in interspecific tomato-potato grafts. HJAR. 42 29-31.

Ogata, T, Kabashima, Y, Shiozaki, S and Horiuchi, S. Regeneration of the vascular bundle at the graft interface in auto and heterografts with juvenile nuclear seedlings of Satsuma Mandrin, yuzu and Trifoliate orange. 2005. Engei Gakkai Zasshi. 74 214-220.

Pulgar, G, Villora, G, Moreno, D.A. and Romero. L. 2000. Improving the mineral nutrition in grafted watermelon plants: Nitrogen metabolism. Plant Bio. 43 607-609.
Rahmatian, A, Delshad, M and Salehi, R. 2014. Effect of Grafting on Growth, Yield and Fruit Quality of Single and Double Stemmed Tomato Plants Grown Hydroponically. J. Hortic. Environ. Biotechnol. 55 115-119.

Ruiz, J.M., Belakbir, A, Lopez-Cantarero, I and Romero L. $1997 . \quad$ Leafmacronutrient content and yield in grafted melon plants: a model to evaluate the influence of rootstock genotype. Scientia Horti. 71 227-234.

Santa-Cruz A, Martinez-Rodriguez, M.M., Perez-Alfocea, F, Romero-Aranda. R and Bolarin M.C. 2002. The rootstock effect on the tomato salinity response depends on the shoot genotype. Plant Science. 162 825-831.

Tamilselvi, N.A. and Pugalendhi. L. 2017. Studies on effect of grafting technique on growth and yield of bitter gourd (Momordica charantia L.) J. Scient. Industr. Res. 76 654-661.

Turkmen, O, Seymen, $\mathrm{M}$ and Dursun.A. 2010. Effects of different rootstocks and cultivars on yield and some yield components of grafted tomato. Bulletin UASVM Horticulture. 67 284-291.

Velkov, N, and Pevicharova. 2016. Effects of cucumber grafting on yield and fruit sensory characteristics. ZemdirbysteAgric. 103 405-410.

\section{How to cite this article:}

Vibhuti Sharma, Pardeep Kumar, Parveen Sharma, N.D. Negi, Amar Singh, Pawan K. Sharma, Navjot Singh Dhillon and Binny Vats. 2019. Rootstock and Scion Compatibility Studies in Tomato under Protected Conditions. Int.J.Curr.Microbiol.App.Sci. 8(05): 1188-1197. doi: https://doi.org/10.20546/ijcmas.2019.805.135 